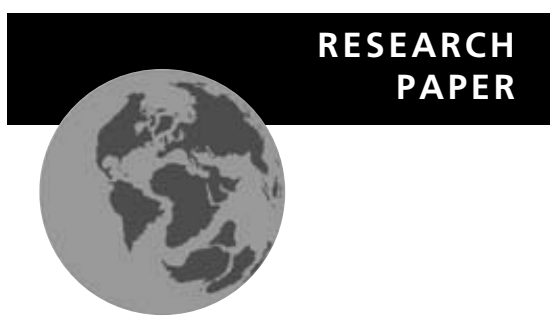

${ }^{1}$ Instituto Nacional de Pesquisas Espaciais, Centro de Previsão de Tempo e Estudos Climáticos (INPE/CPTEC), Cachoeira Paulista, 12630-000 SP, Brazil, ${ }^{2}$ Instituto de Aeronáutica e Espaço - Centro Técnico Aeroespacial (IAE/CTA), São José dos Campos, 12228-040 SP, Brazil

${ }^{*}$ Correspondence: Manoel Cardoso, Instituto Nacional de Pesquisas Espaciais, Centro de Previsão de Tempo e Estudos Climáticos (INPE/CPTEC), Cachoeira Paulista, 12630-000 SP, Brazil.

E-mail: mcardoso@cptec.inpe.br

\section{Long-term potential for fires in estimates of the occurrence of savannas in the tropics}

Manoel F. Cardoso ${ }^{1, \star}$, Carlos A. Nobre ${ }^{1}$, David M. Lapola ${ }^{1}$, Marcos D. Oyama ${ }^{2}$ and Gilvan Sampaio ${ }^{1}$
ABSTRACT
Aim This study aims to improve the formulation and results of the Brazilian Center for Weather Forecasting and Climate Studies Potential Vegetation Model (CPTECPVM) by developing a new parameterization for the long-term occurrence of fire in regions of potential savannas in the tropics. Compared with the relatively slow processes of carbon uptake and growth in vegetation, fast mortality and biomass consumption by fires may favour grasses and reduce tree coverage.

Location The tropics.

Methods For finding large-scale relationships between fires and other environmental factors, we made two main simplifying assumptions. First, lightning is the most important source of ignition for natural fires. Second, over continental areas in the tropics, lightning is mainly related to the zonal flux of moisture transport.

Results The parameterization of fire occurrence was built based on a simple empirical relationship, combining information on mean and intra-annual variance of the zonal wind.

Main conclusions The implementation of this new relationship improved the formulation and the results of the CPTEC-PVM. As a result of this new parameter, the accuracy of the model in allocating the correct vegetation (seasonal forests) instead of savannas for large regions in India and Southeast Asia is now substantially higher than in previous studies.

\section{Keywords}

Biome, CPTEC-PVM, dry forest, fire, savanna, vegetation model.

\section{INTRODUCTION}

Potential vegetation/biome models are useful tools for representing biosphere-atmosphere interactions on a large temporal and spatial scale for climate and environmental studies (Prentice et al., 1992, Neilson, 1995; Haxeltine \& Prentice, 1996; Pearson \& Dawson, 2003). These models summarize the broad relationships between vegetation and climate (e.g. Holdridge, 1967; Whittaker, 1975), and allow estimation of the potential natural (not considering land use) land cover corresponding to particular climate conditions. Assuming long-term biosphere-atmosphere equilibrium, these relations are also useful for evaluating potential climatic conditions that correspond to a given biome configuration (Bonan, 2002). For example, the coupling of climate and potential vegetation models allows the estimation of bidirectional long-term climate change in response to modifications in the land surface (Oyama \& Nobre, 2003, 2004a). The combination of relative simplicity, a small number of parameters (mainly surface temperature and precipitation) and efficiency at large scales favours the interpretation of results and encourages the further development of potential biome models (Pearson \& Dawson, 2003).

The Brazilian Center for Weather Forecasting and Climate Studies Potential Vegetation Model (CPTEC-PVM) (Oyama \& Nobre, 2004b) has been used for coupling to the CPTEC Atmospheric Global Circulation Model (AGCM) (Cavalcanti et al., 2002) as well as in several studies evaluating large-scale climatevegetation interactions. For example, using the CPTEC-PVM, Oyama \& Nobre (2003) indicated the possibility of a different equilibrium state between current climate conditions and biome distribution in tropical South America, where eastern Amazonian forests are replaced by savannas and the driest portion of north-east Brazil becomes a semi-desert. In another study, Oyama \& Nobre (2004a) found that ongoing environmental 


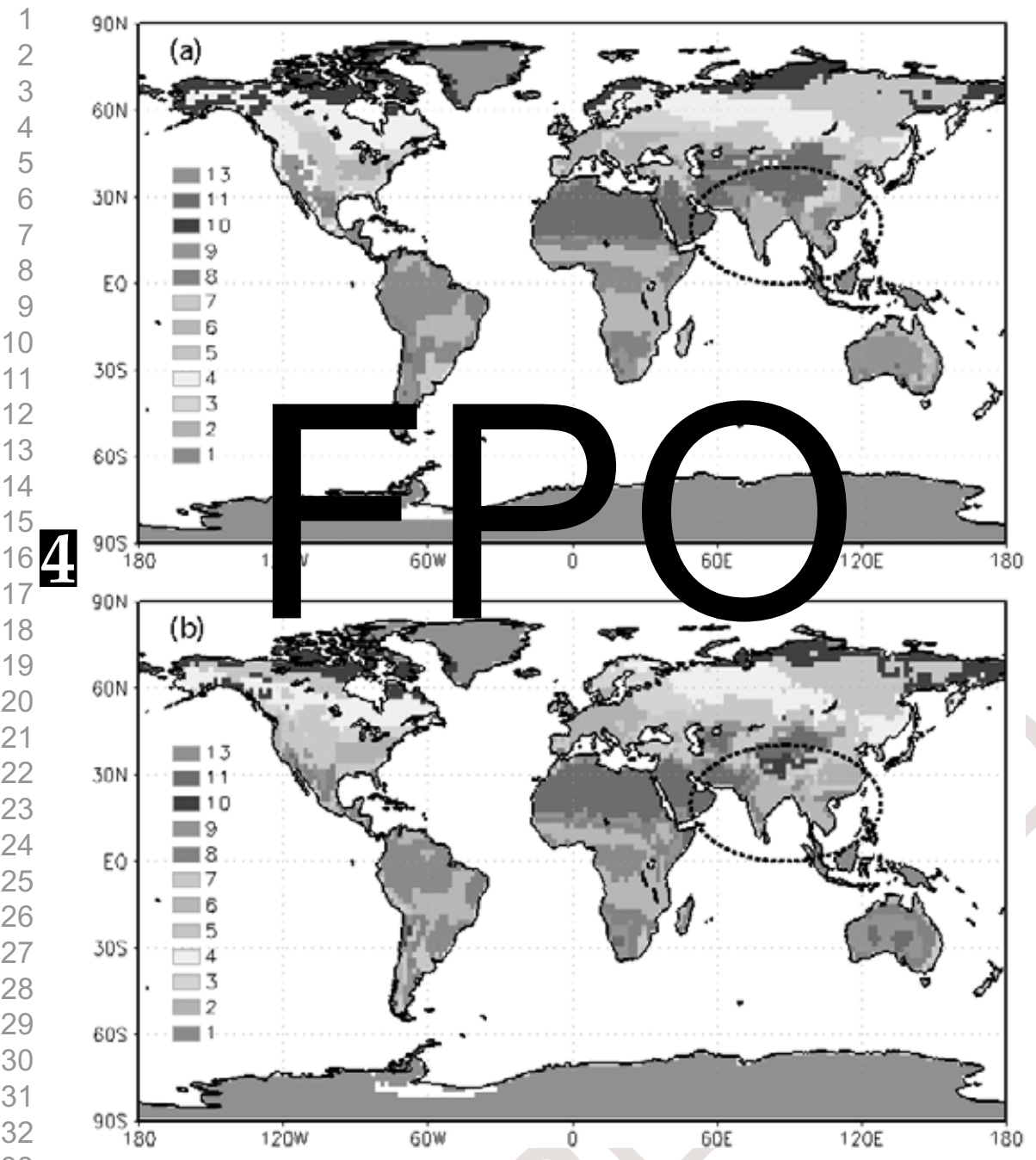

Figure 1 Global vegetation maps.

(a) Reference natural vegetation and (b) potential vegetation estimated with the CPTEC-PVM (Oyama \& Nobre, 2004b). Vegetation types follow the same classification used in Oyama \& Nobre (2004b):

(1) broadleaf-evergreen trees (tropical forest), (2) broadleaf-deciduous trees (temperate forest), (3) broadleaf and needleleaf trees (mixed forest), (4) needleleaf-evergreen trees (boreal forest), (5) needleleaf-deciduous trees (larch), (6) broadleaf trees with groundcover (savanna), (7) groundcover only (prairie, steppes), (8) broadleaf shrubs with perennial groundcover (caatinga), (9) broadleaf shrubs with bare soil (semi-desert), (10) dwarf trees and shrubs with groundcover (tundra), (11) bare soil (desert) and (13) ice. Dotted black lines indicate regions with important differences between the two maps. degradation in north-eastern Brazil may lead to regional weakening of the hydrological cycle and important large-scale change in precipitation patterns.

Based on dominant climate and soil hydrology characteristics (growing degree days, temperature of the coldest month, soil moisture seasonality and evapotranspiration), the CPTEC-PVM is able to reproduce most ( $62 \%$ of grid cells, at c. $2^{\circ}$ spatial resolution) of the present-day natural features of the vegetated land surface globally. For South America, where applications of the CPTEC-PVM are concentrated, the performance of the model is higher (c. $68 \%$ of the grid cells). In spite of reasonable performance and simplicity, there is interest in improving the formulation and the results of the model. In particular, there is interest in expanding the capability of the model to account for additional factors affecting biome distribution, and in improving the results of the model for regions of savannas in the tropics.

The CPTEC-PVM indicates that the natural vegetation in large regions in India and Southeast Asia is savanna (Oyama \& Nobre, 2003) (Fig. 1b). Reference studies (e.g. Jha \& Singh, 1990; Sagar \& Singh, 2005) and maps (e.g. Matthews, 1983; Ramankutty \& Foley, 1999), however, indicate that the natural vegetation in those regions is dry tropical and subtropical forests
(Dorman \& Sellers, 1989) (Fig. 1a). This difference is also present in results from other models (Oyama \& Nobre, 2004b), and is presumably caused by difficulties in reproducing soil hydrology (Haxeltine \& Prentice, 1996; Hickler et al., 2006), the potential for species adaptation (Eyre, 1968; Pearson et al., 2006) and the occurrence of disturbances such as fires (Daly et al., 2000, Bond et al., 2005).

It makes sense to pay attention to fires when analysing the differences for tropical savannas in Fig. 1(a) and (b) (Bond \& Keeley, 2005). Fires are major natural disturbances with a strong potential for affecting the establishment of savannas in the tropics (Ramos-Neto \& Pivello, 2000; Bond et al., 2005). Grasses have vital parts below the ground and may be able to regrow after fires. The mortality of trees and seedlings due to fire, on the other hand, may prevent regeneration of woody species (Uhl \& Kauffman, 1990; Cochrane \& Schulze, 1999). While several factors may combine to determine the exact boundaries between forests and savannas (Scholes \& Archer, 1997; Mistry 1998), long-term biomass consumption and mortality due to fires are higher for trees than for grasses, and may favour the occurrence of savannas in the place of forests (Bachelet et al., 2000; Daly et al., 2000; Hoffmann et al., 2000). 
Several independent studies have also shown the important effect of fires on the relative distribution of forests and savannas. For example, modelling estimates of vegetation distribution by Bond et al. (2005) indicate that, globally, forest coverage would increase from $27 \%$ to $56 \%$ of the entire vegetated surface if there was a complete absence of fires. Other analyses at small scales by Daly et al. (2000) and Bachelet et al. (2000) discuss the importance of fires in the relationship between trees and grasses. They show that fires can reduce trees biomass and shading effects over grasses. In turn, the presence of grasses increases fuel load and favours fires. Deep roots allow trees to resist drought and expand over grasses, thus causing a reduction of fuel load and fire frequency (Bachelet et al., 2000; Daly et al., 2000). According to Keeley \& Rundel (2005), climate-induced occurrence of fires caused a substantial expansion and maintenance of grasslands in tropical and sub-tropical regions after the Miocene.

In order to improve the formulation and results of the CPTEC-PVM we developed a simple parameterization for representing the broad-scale long-term likelihood of natural fires in savannas. The analyses were concentrated on regions with climate potential for the establishment of savannas in the tropics and subtropics, and were designed to search for a general parameter that can be calculated from the large-scale meteorological outputs from global climate models.

\section{METHODS AND RESULTS}

\section{Drivers for large-scale occurrence of fires in savannas}

Vegetation fires can be generally described as the combination of the presence of fuel, high flammability and ignition sources (Rothermel, 1972). In regions of savannas, climate seasonality (with distinct wet and dry seasons) provides favourable conditions for at least two of these major fire factors: fuel and flammability (Scholes \& Archer, 1997). While precipitation favours biomass/fuel build-up during the rainy season, dry and hot conditions favour the increase of flammability during the dry season (Mistry, 1998). In addition, the high primary productivity of grasses can lead to high fine-fuel loads that allow for intense and fast fire fronts (Kauffman et al., 1994).

Based on the relatively short time-scales for the growing season and changes in moist/dry conditions in the above-ground biomass in savannas, these regions can present favourable fuel and flammability conditions on a yearly basis (Bonan, 2002). Assuming that fire occurrence in savannas is not limited by either of these two major factors, it is likely that the presence of ignition sources has a major impact on the long-term potential for fires in these regions. Based on this assumption, we started to conceive a parameterization for long-term fires in savannas centred on the potential for natural sources of ignition in these areas.

\section{Lightning as a major source of ignition for natural fires in savannas}

Several studies indicate that lightning is the main source of ignition for natural fires. For example, observations by Ramos-Neto
\& Pivello (2000) show that lightning was the most important source of ignition for natural burnings in the Emas National Park located in the Brazilian savanna, from June 1995 to May 1999. In that study, most of the burning occurred between September and May caused by natural fires in the transitions from the dry to the rainy season (September-October), and the highest value of area burned and the second highest number of fires occurred in September. In the same study, the authors also pointed out that the natural fire regime in the Brazilian savanna is not well documented, and natural lightning fires in this region have been wrongly assumed to be rare.

Research for other regions also supports the notion that lightning is a major natural source of ignition. Price \& Rind (1994) projected favourable conditions for natural fire activity in the USA based on the expectation for increased lighting activity caused by a doubling of the concentration of $\mathrm{CO}_{2}$ in the atmosphere. Projections of fire danger by Brown et al. (2004) centred on lightning as the main sources of ignition for natural fires in the western USA. Global fire rules in Neilson (1995) are centred on fuel and lightning/ignition conditions inferred from the intensity of rainfall in the summer. Based on results from studies such as the ones mentioned above, we designed a parameterization for long-term fire activity in savannas in the tropics by searching for large-scale factors that can favour lightning activity over these regions.

\section{Patterns of lightning-causing factors over regions of potential savannas in the tropics}

Lightning activity can be primarily classified into intra-cloud, cloud-to-cloud and cloud-to-ground events (Barry \& Chorley, 1998). In our case, the ideal analysis for identifying factors related to lightning/ignition in tropical savannas would be based on long-term data on cloud-to-ground lightning events. To our knowledge, however, such a data set covering all of the tropics is not currently available. Current (1995-present) lightning information from remote sensing is in fact accessible (Petersen et al., 2002; Christian et al., 2003) and provides estimates of total lightning activity. One difficulty with using these data in our analysis is that the cloud-to-ground fraction varies substantially in space and time and may not be directly distinguished from total lightning information (Price \& Rind, 1994; Pinto \& Pinto, 2003).

Remote-sensing records of total lightning activity span $c .12$ years and may represent climatological information on total lightning activity in the tropics. Comprehensive relationships between these data and other environmental variables, however, are the subjects of ongoing research (Boccippio et al., 2000; Cecil et al., 2005, Petersen etal. 2006; Schumaker \& Houze, 2006; Takayabu, 2006). We consider that finding these relationships for climatological cloud-to-ground lightning estimates in the tropics is outside the scope of this paper. As described below, the approach we adopted here for evaluating the large-scale potential for lightning was to analyse factors that can be studied using simple and broad mechanisms and information from climatological data sets. We then proceed with the basic and simple idea that 


\section{F. Cardoso et al.}

the dominant process for lightning activity in the tropics is deep convection of atmospheric moisture (Price \& Rind, 1994; Barry \& Chorley, 1998).

At the large scale, the oceans are the main source of atmospheric moisture (Schlesinger, 1997). Generally, over the continents, the availability and flow of moisture are linked to the transport of the water vapour by prevailing winds and to the characteristics of land surface (McGregor \& Nieuwolt, 1998). Generally, the position of the land masses in relation to the oceans and major circulation patterns and the gradients of the topography are major large-scale factors affecting tropical atmospheric moisture (Barry \& Chorley, 1998). Topography is important because it can mechanically force air parcels to rise as they move along the land surface (e.g. Sklenar \& Lægaard, 2003; Xie et al., 2006). As temperature decreases with altitude, atmospheric moisture content tends to decrease due to condensation and orographic precipitation, leading to potentially wetter (drier) regions located windward (downwind) from elevated topography (Barry \& Chorley, 1998; McGregor \& Nieuwolt, 1998). Similarly, the likelihood of lightning activity is higher (lower) on the windward (downwind) side of mountains.

In line with our goal of using broad mechanisms and climatological data sets for studying the long-term potential for fire in savannas, we adopt a simple perspective based on finding relative patterns between large-scale atmospheric circulation, topography and the potential for savannas in the tropics. To this end, we performed the three analyses below. In Analysis 1, we combined data on long-term wind patterns and major elevation features and constructed back trajectories of the air near the surface for regions estimated as savanna by the CPTEC-PVM. In Analysis 2, we explored major indications from Analysis 1 by relating major circulation patterns to the position of tropical savannas estimated by the CPTEC-PVM. In Analysis 3, we used available estimates of lightning activity at large spatial scales from remote-sensing to evaluate the relationships found in the previous analysis.

\section{Analysis 1 - air trajectories during dry-wet season transitions}

In this analysis, we calculated trajectories representing the average movement of the air near the top of the boundary layer (at the pressure level of $850 \mathrm{hPa}, c .1 .5 \mathrm{~km}$ above the surface) upwind from the study regions and during the transition between the dry and wet season, when the effects of lightning on fire ignitions are expected to be highest. Wind monthly climatology and topography data are from the National Centers for Environmental Prediction/National Center for Atmospheric Research (NCEP/ NCAR) reanalysis monthly means (Kalnay et al. 1996), also used in the other analyses below. Transitions between dry and wet seasons were defined here as the two subsequent months after the driest month, calculated based on monthly precipitation climatology from Willmott \& Matsuura (1998).

The study areas are displayed in Fig. 2(a), and were set according to their timing for the transition from dry to wet seasons. Potential savannas (in yellow) are shown, together with information on elevation (contour lines). Grey and red lines represent altitudes of $1000 \mathrm{~m}$ and $2000 \mathrm{~m}$, respectively. Outside the polygons, average altitude is lower than the corresponding isoline value. Potential savannas in Mexico and Central America are in area $\mathrm{A}$, where the transition from dry to wet season estimated from precipitation climatology occurs during April-May. Estimated climatological dry-to-wet season transitions for northern (north of the Equator) South America (B) occur in March-April, and for southern (south of the Equator) South America (C) in September-October. These transitions in northern Africa (D) were estimated as occurring in February-March, in southwest Africa (E) as occurring in September-October and for south-east Africa (F) in August-September. In India (G) and Southeast Asia $(\mathrm{H})$, the transitions are expected to occur in April-May and in March-April, respectively, and in Australia (I) in October-November.

As shown by the other panels in Fig. 2, the air trajectories follow the large-scale circulation represented by the average wind field (in grey vectors) for the period estimated for the transition between dry and wet seasons. Air trajectories were limited to cover a region of approximately $5000 \mathrm{~km}$, set as a reasonable distance for studying influences from the surrounding areas. In Mexico and Central America (Fig. 2b), northern South America (Fig. 2c) and southern South America (Fig. 2d), not all trajectories pass through areas with elevated topography. Most of the length of these trajectories is over the ocean, with a few exceptions in the south-western portion of southern South America. Some areas are also located in regions with positive gradients of topography relative to the air trajectories, in the vicinity of the Sierra Madre in Mexico (Fig. 2b) and the Andes in Peru, Bolivia and northern Argentina (Fig. 2d).

Air trajectories for the western and central portions of northern Africa (Fig. 2e) are mostly over the continent. Some of these trajectories show air movement from the north without crossing gradients of topography. Other trajectories show air coming from the south, downwind from mountains in southern (between Angola and Tanzania) Africa. For the eastern portion of this subregion (in Uganda, Kenya and Ethiopia), air trajectories are mostly over the ocean and lead to positions located on or near steep terrain (1000-2000 m). Trajectories for the east and south of south-west Africa (Fig. 2f) present nearly half of their extent over the Indian Ocean, and show air movement crossing regions of mountains in Zambia and Tanzania. In south-east Africa (Fig. 2g), the length of air trajectories is mostly over the ocean, with one exception in the north-west extreme of this subregion. These trajectories are aligned with a positive gradient of topography along northern Mozambique and Tanzania, and indicate progressive large-scale rising of air from the Indian Ocean. Nearly half of the area of potential savannas in this subregion is located in the south-east, towards the coast in Mozambique and along the $1000 \mathrm{~m}$ elevation line (along eastern Zambia and central Tanzania).

In India (Fig. 2h) and in the northern portion of Southeast Asia (in Burma and Laos) (Fig. 2i), nearly the whole extent of air trajectories is located over the continent, and they extend across areas with steep topography near the Himalayas and between Iran and Turkey. In other parts of Southeast Asia (Thailand to 
Figure 2 Regions for the air trajectories analyses. Potential savannas as estimated by the CPTEC-PVM are in yellow. In (a) blue rectangles highlight the regions divided according to their timing for dryto-wet season transitions: April-May in Mexico and Central America (region A); March-April in northern (north of the Equator) South America (B); SeptemberOctober in southern (south of the Equator) South America (C);

February-March in northern Africa (D); September-October in south-west Africa (E); August-September in southeast Africa (F); April-May in India (G); March-April in Southeast Asia (H); and October-November in Australia (I). Contour lines represent major topography. Brown and red lines correspond to average altitudes of $1000 \mathrm{~m}$ and $2000 \mathrm{~m}$,

respectively. Panels (b)-(j) show air back trajectories (in red, limited to $c .5000 \mathrm{~km}$ ) for regions $\mathrm{A}$ to $\mathrm{I}$, along with average vector fields at $850 \mathrm{hPa}(c .1 .5 \mathrm{~km}$ height) in $\mathrm{m} \mathrm{s}^{-1}$, during dry-to-wet season transitions. Wind climatology and topography data are from the NCEP/NCAR reanalysis monthly means (Kalnay et al. 1996).
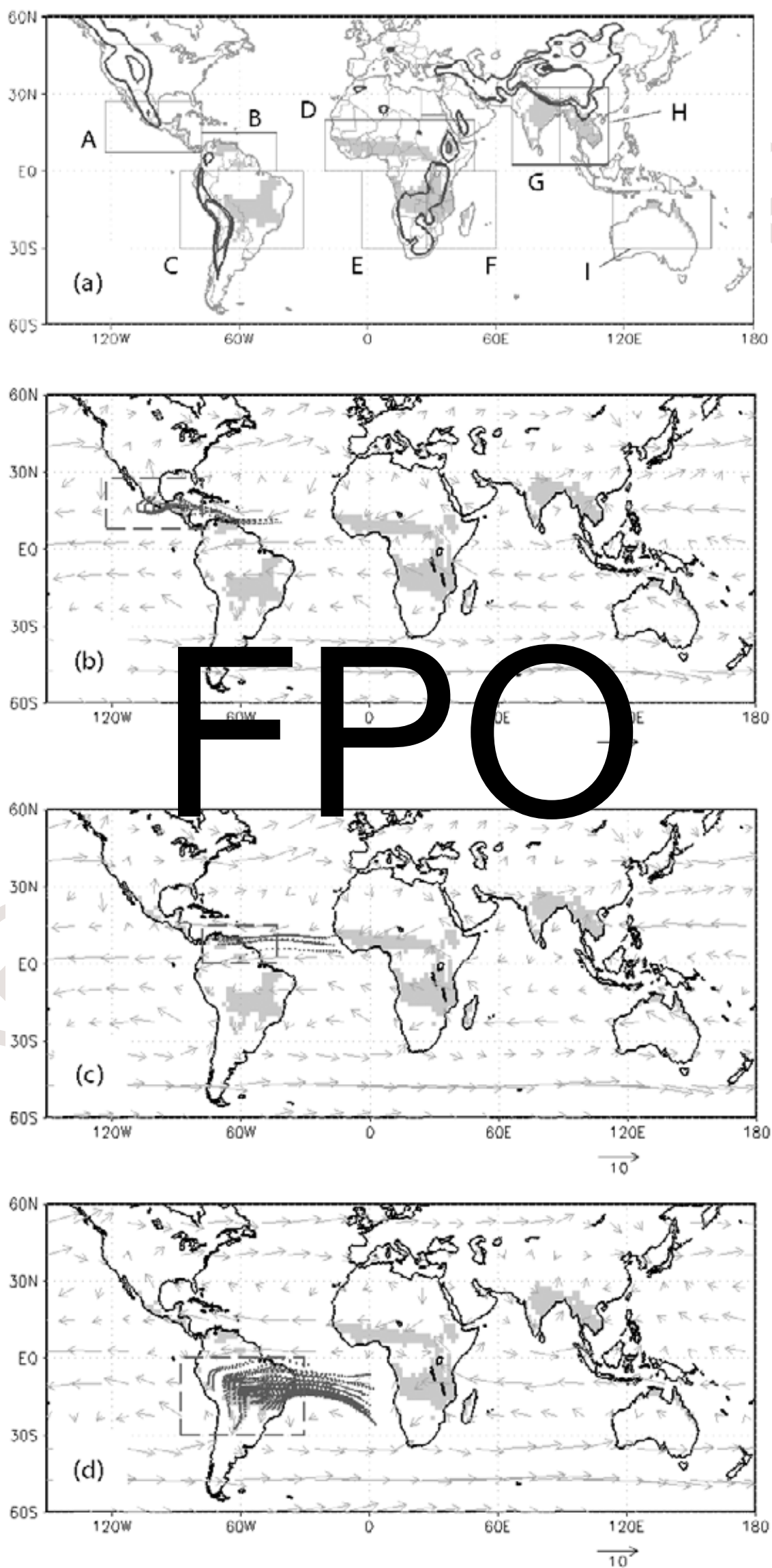
M. F. Cardoso et al.
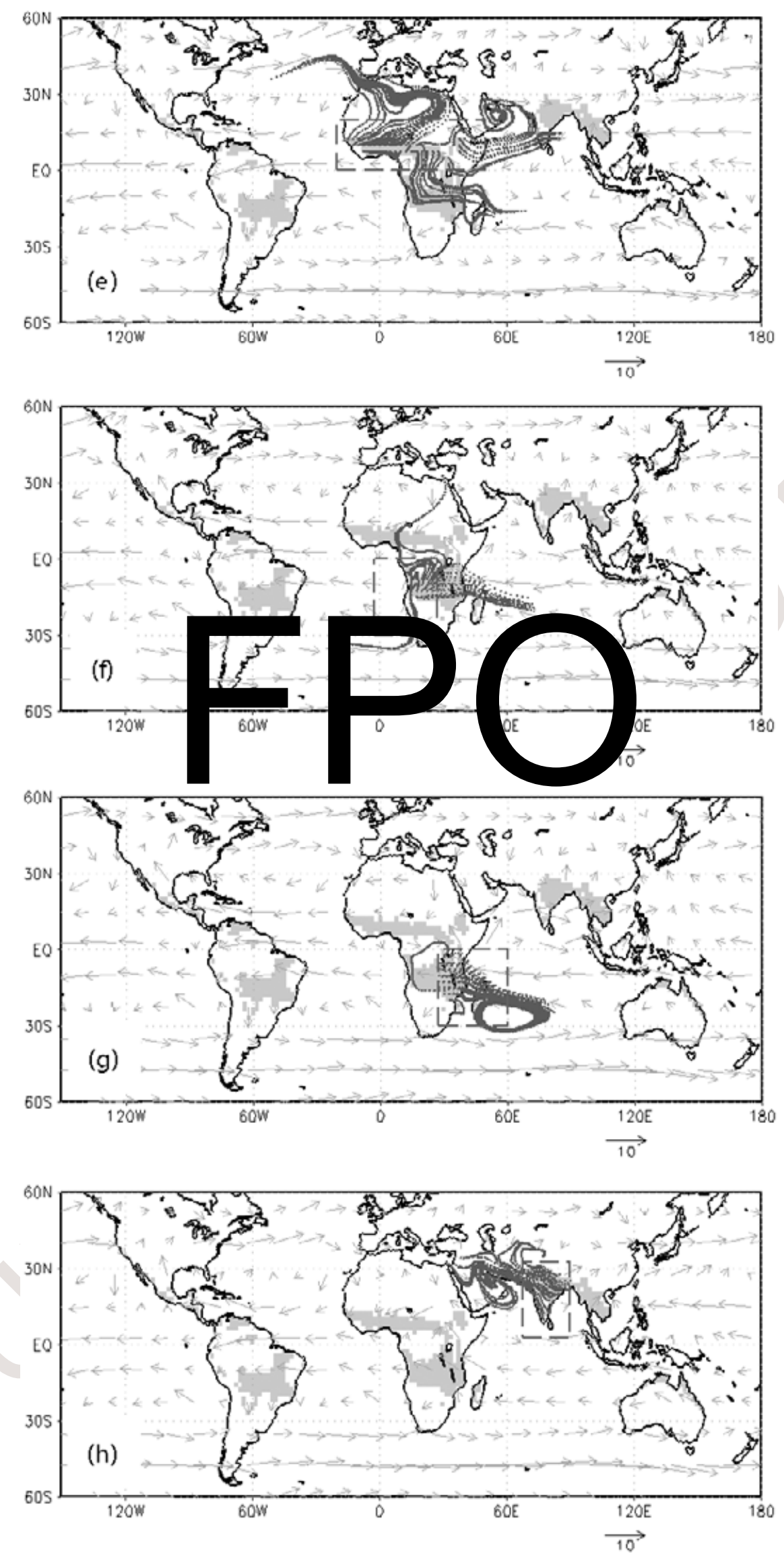

Figure 2 Continued 
Figure 2 Continued

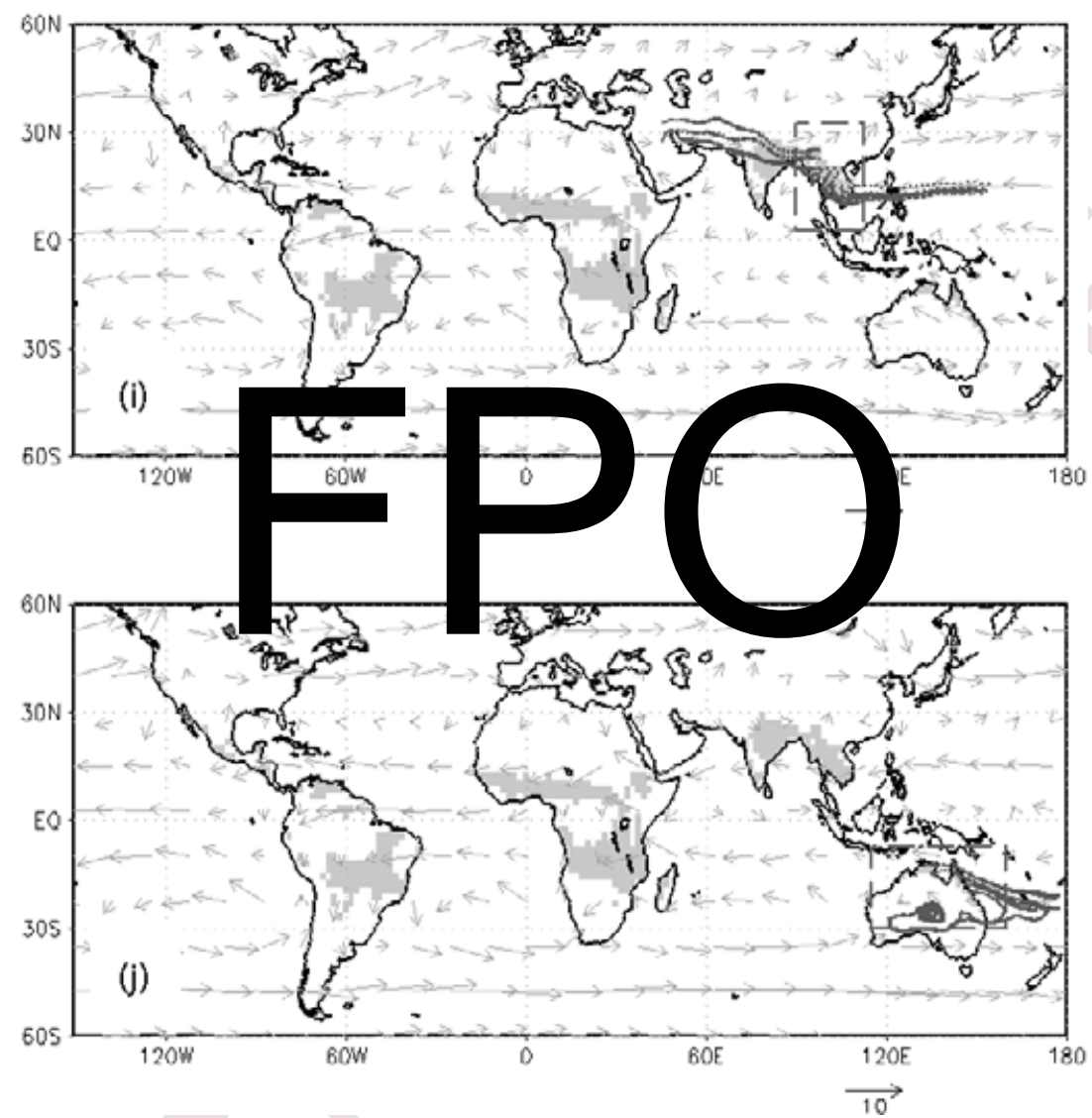

Vietnam), the air trajectories present most of their portions covering the ocean and do not cross areas with average high altitudes. One relatively small area near the north of Thailand, between Burma and Laos, is located on ascending topography relative to the air trajectories. Potential savannas in Australia (Fig. 2j) generally present air trajectories with the majority of their length over the ocean, without crossing gradients of topography.

This analysis suggests that there are important differences in the characteristics of the air trajectories in the studied regions during transitions from dry to wet seasons. Thus, air trajectories for potential savannas in India and northern South Asia cover long distances away from the ocean (the major large-scale source of water vapour) and cross regions with high topography. Generally, for inner portions of Africa (west of northern Africa, and most of south-west Africa) the air trajectories are mainly over the continent and show air movement crossing mountains on the south-east. In contrast, potential savannas in the Americas, Australia, eastern portions of Africa (east of northern Africa, and most of south-east Africa) and southern South Asia have air trajectories that are mostly over the ocean and do not cross areas with elevated topography.

To test the sensitivity of these results to the definition of the dry-to-wet season transitions used here, we also performed two sensitivity analyses. In one sensitivity analysis, the air trajectories were recalculated considering that the dry-to-wet period could occur 1 month earlier than that initially selected. In other sensitivity analyses, the trajectories were recalculated considering that the transitional period could occur 1 month later than that originally set. For example, the trajectories for Mexico and Central America in Fig. 2(b) were calculated using monthly wind fields averaged over the months of April and May. Accordingly, in the first sensitivity analysis the trajectories for Mexico and Central America were recalculated using average wind fields for the months of March and April. In the second sensitivity analysis for that region, the trajectories were recalculated using average wind fields for May and June. In all cases, the trajectories resulting from both sensitivity analyses presented large-scale patterns that are similar to the patterns displayed in Fig. $2(\mathrm{~b})-(\mathrm{j})$ and are therefore not shown here.

Using the simple large-scale mechanism for atmospheric moisture in the tropics described in the preceding section, the differences between the air trajectories in Fig. 2 can be qualitatively associated with differences in the potential for lightning activity. Essentially, the differences indicate that at large temporal and spatial scales, regions of potential savannas in the Americas, Australia, eastern portions of Africa and southern portions of South Asia present a higher likelihood of lightning activity during dry-to-wet season transitions than regions of potential savannas in India, northern South Asia and most of the western portions of Africa. These patterns thus indicate that the position of potential savannas can also be associated with large-scale wind 


\section{F. Cardoso et al.}

patterns. Based on this indication, we performed the following analysis.

\section{Analysis 2-long-term wind patterns and allocation of potential savannas}

Analysis 1 indicates that most regions of potential savannas with distinct long-term potential for lightning during dry-to-wet season transitions in the tropics can be generally related to air masses moving predominantly from east to west (Fig. 3a). This pattern is important because it indicates the possibility of finding a general rule for parameterization of long-term potential for lightning/ignition that is very simple and based only on the main patterns of atmospheric circulation at low to mid levels $(850 \mathrm{hPa})$ (Laurent et al., 2002; Petersen et al., 2002).

From that indication, we then searched for long-term wind characteristics that are consistent with the patterns from the broad-scale rain-shadow analysis above and which could explain the differences between the maps of natural vegetation of Fig. 1 . To represent broad-scale circulation patterns, we selected the zonal component (along parallels of latitude) of the wind, which is the major direction of air flow for low levels in the tropics. To represent major characteristics of this flow, we calculated the long-term average and the intra-annual variance of the zonal wind. The long-term average was derived by computing the sum of all climatological monthly values divided by 12 (the total number of climatological monthly data layers), for each grid cell. This average captures the prevailing intensity and direction of the zonal wind, and has the same units as the wind data set $\left(\mathrm{m} \mathrm{s}^{-1}\right)$, where positive values mean air movement in the west to east direction.

The intra-annual variance of the zonal wind was derived by computing the sum of the squared deviations of climatological monthly values from their long-term mean, for each grid cell. This metric is a measure of the fluctuation of the zonal wind within a year. Because of the calculation process, the intra-annual variance of the zonal wind has units of squared velocity $\left(\mathrm{m}^{2} \mathrm{~s}^{-2}\right)$, and is always positive. Small values represent little variation in intensity and/or direction of the zonal wind. Conversely, larger values delineate regions with larger fluctuations. We found that depending on the product between the long-term average (signal of prevailing direction) (Fig. 3a) and the intra-annual variance (signal of alternation) (Fig. 3b) of the low-level component of the zonal wind, most regions of potential savannas could be differentiated according to the results from the air trajectories analysis (Fig. 3c). Here the units of $\mathrm{m}^{3} \mathrm{~s}^{-3}$ do not necessarily have a physical meaning, but derive from the calculation process.

We identified that for values of the multiplication between the long-term average and intra-annual variance of the zonal wind above $3.5 \mathrm{~m}^{3} \mathrm{~s}^{-3}$, the potential savannas in India and Southeast Asia are differentiated from other major regions of savannas worldwide (Fig. 3d). This simple pattern relates long-term lightning activity to the position of most natural savannas in the tropics, and can be used as an empirical relationship to refine estimates of potential vegetation maps. Applying this result to the outputs of the CPTEC-PVM, the regions initially estimated as savannas were confirmed if they were inside the areas defined by the threshold in Fig. 3(d), or corrected to dry forests otherwise. As shown in Fig. 4, this application increased the accuracy of the CPTEC-PVM for regions of savanna. In particular, the large regions in India and Southeast Asia that were initially estimated as savannas were corrected to dry forests. Most of the savanna regions that were correctly classified in the Americas, Africa and Australia were unaffected by the simple rule. In the next analysis we then evaluate this simple rule by using large-scale lightningactivity data as detected by satellites.

\section{Analysis 3 - evaluation of the simple fire rule using lightning data from satellites}

In this analysis we aim to evaluate how the previous results (from Analysis 2) are supported by the available records of lightning activity at large spatial scales, which are currently derived from remote-sensing observations. To this end, we compared wind and lightning activity during the transition between dry and wet seasons (Fig. 5). As in Analysis 2 above, we used monthly climatologies of the zonal component of the wind at the pressure level of $850 \mathrm{hPa}$. Lightning data are monthly global climatologies of total (cloud-cloud and cloud-ground) lightning flashes detected by the Lightning Imaging Sensor (LIS) and the Optical Transient Detector (OTD) from 1995 to 2003, provided by the Global Hydrology Resource Center (http://thunder.nsstc.nasa.gov). Because cloud-ground events (the fraction that can cause fire) may not be directly identified from all detected flashes (Price \& Rind, 1994; Pinto \& Pinto, 2003), the remote-sensing lightning data are used here as an indication of the climatological total lightning activity at large scales in the tropics.

As indicated in Fig. 5(a) and (b), there are correspondences between zonal wind and lightning during dry-wet season transitions. In particular, during these transitions, the prevailing wind direction in India and Southeast Asia is westerly, and in South America and Africa it is mostly easterly (Fig. 5a), while the lightning activity in India is generally lesss than in South America and Africa (Fig. 5b). In this analysis, we also verified that the threshold of $1.5 \mathrm{~m} \mathrm{~s}^{-1}$ of the zonal wind (Fig. $5 \mathrm{c}$ ) outlines most of the regions where the CPTEC-PVM wrongly assigns savannas. According to the patterns in Fig. 5(c), most of the potential savannas wrongly assigned in India and Southeast Asia by the CPTEC-PVM can be corrected, without reducing the model accuracy for other regions in South America, Africa and Australia. These patterns are similar to those defined by the simple fire rule in Analysis 2, thus supporting that parameterization.

\section{DISCUSSION AND CONCLUSIONS}

In spite of the substantial progress achieved in building and using inclusive process-based ecosystems and biogeochemical models in environmental studies (e.g. Foley et al., 1996; Hickler et al., 2006; Kucharik, 2003), broad analyses of the climate-vegetation equilibrium at large temporal and spatial scales can be properly 
Figure 3 Long-term global circulation patterns at $850 \mathrm{hPa}$. Panel (a) displays the average wind field with vectors in $\mathrm{m} \mathrm{s}^{-1}$ (black) and stream lines (yellow). Areas where prevailing zonal wind is from the east are in grey, and from the west in white. Intra-annual variance of the zonal wind is shown in (b). Panel (c) shows the combined (multiplied) long-term average and intra-annual variance of the zonal wind. Panel (d) shows the optimum threshold value of the field in (c) to differentiate between regions of potential savannas with and without $\left(\geq 3.5 \mathrm{~m}^{3} \mathrm{~s}^{-3}\right.$ in grey) long-term likelihood for lightning activity (and thus occurrence of natural ignition sources for fires) during dry-towet season transition. Wind climatological data are from the NCEP/NCAR reanalysis monthly means (Kalnay et al. 1996).
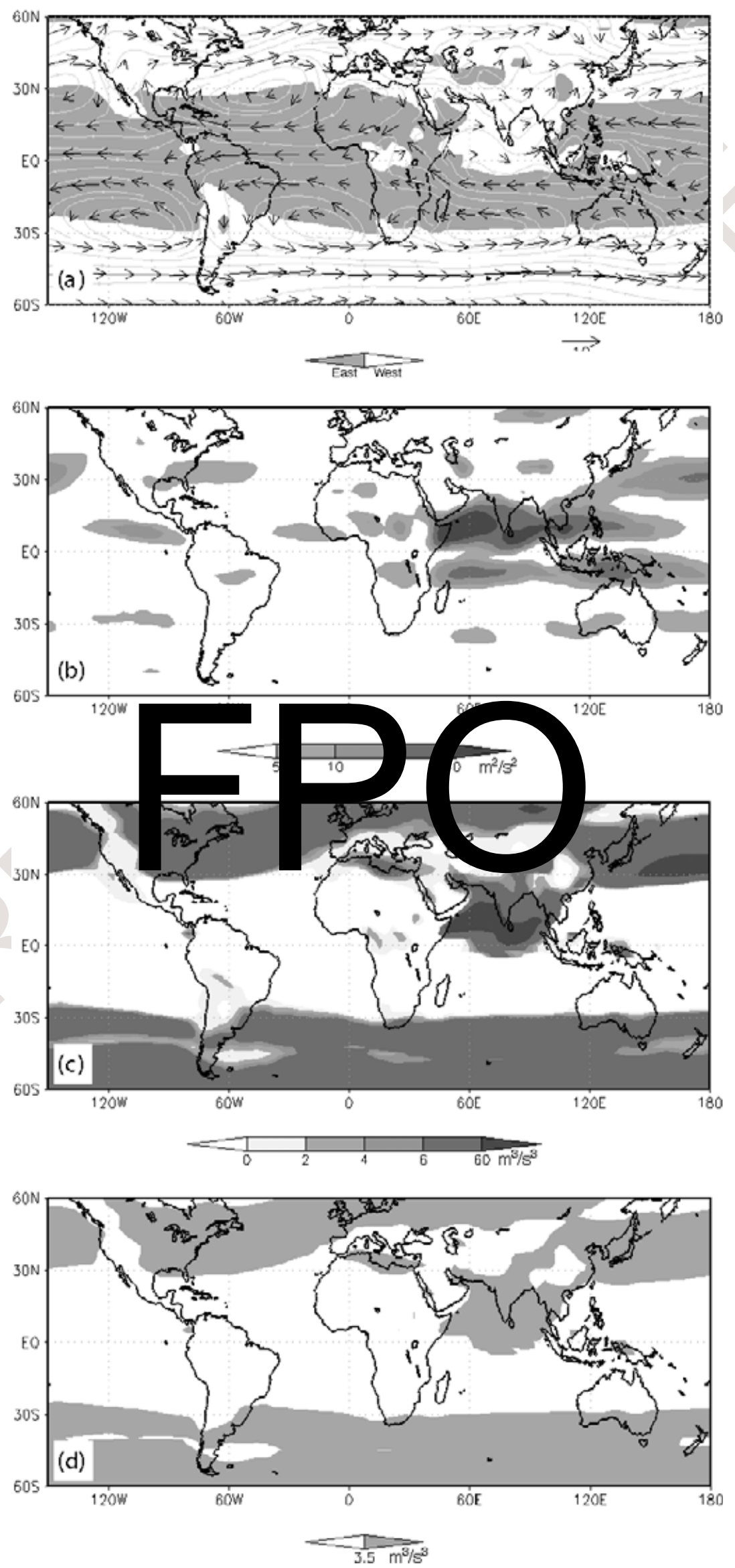


\section{F. Cardoso et al.}

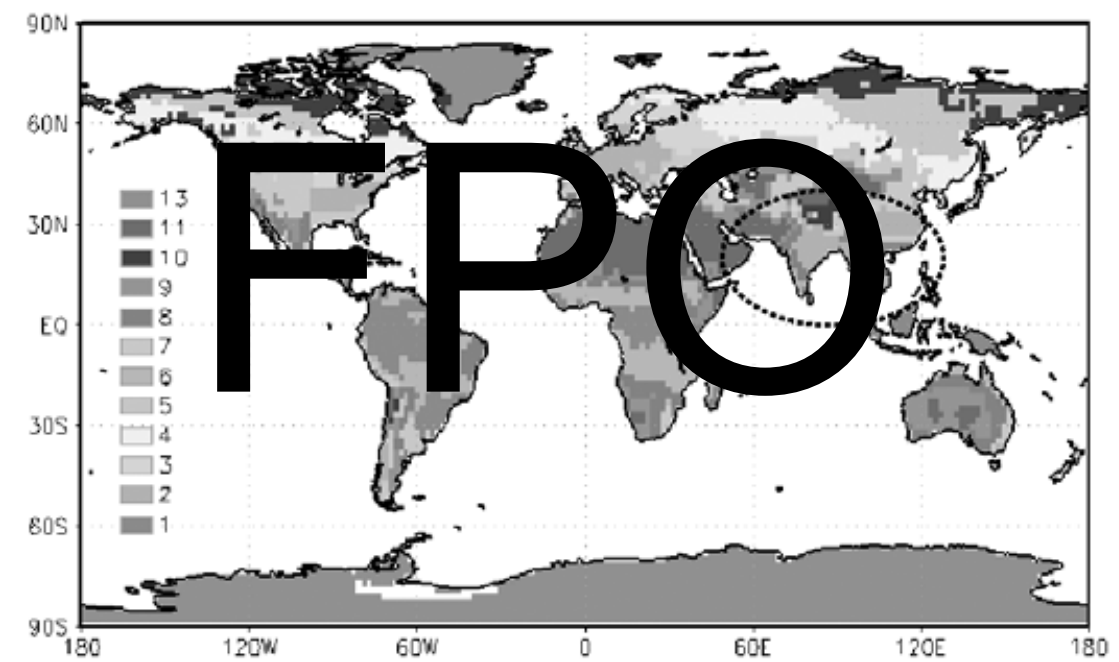

Figure 4 Potential vegetation estimated with the CPTEC-PVM using a new parameterization for representing long-term potential for fires in savannas. Accounting for fires improved the results of the CPTEC-PVM, correcting important differences between previous model estimates and reference data for the position of natural savannas in the tropics. In relation to the maps in Fig. 1, large areas in India and Southeast Asia that were initially estimated as savannas are now corrected to dry forests. Dotted black lines indicate regions with important improvements. performed with simpler potential vegetation models (e.g. Neilson, 1995; Pearson \& Dawson, 2003; Oyama \& Nobre, 2004a). Their relative simplicity in using and interpreting results, and suitability for broad-scale estimates, thus encourages the further improvement of these models. In order to advance the formulation and results of the CPTEC-PVM, we developed a new parameterization for long-term occurrence of fire in regions of potential savannas in the tropics, assuming that lightning is the major natural source of ignition for vegetation fires, as described in Analysis 2.

The new fire parameterization is based on a simple empirical relationship between large-scale circulation patterns at low-mid levels in the atmosphere and the position of savannas according to reference natural vegetation data. This relationship was inferred by evaluating the long-term potential for lightning during the transition from dry to wet seasons, given by a qualitative analysis of air trajectories along major topographical features in the tropics. The relationship was quantified using information on long-term average and intra-annual variance of the zonal wind, and is generally supported by large-scale total lightning-activity information detected from satellites. The rule is applied to current estimates of the CPTEC-PVM by confirming model assignments of savannas if there is indication of long-term occurrence of lightning that can naturally cause fires. This combination corrected major differences between the model estimates and reference data for the position of natural savannas in the tropics. Specifically, large areas in India and Southeast Asia that were initially estimated as savannas are now corrected to dry forests.

Analysis 1 gave major indications for the fire parameterization built in the subsequent analysis. The analysis explains important differences between the CPTEC-PVM estimates and reference natural vegetation data for savannas in India and most of Southeast Asia, as shown in Fig. 1. It is also in agreement with similarities between model and data for South America, Australia and eastern Africa. Some exceptions occurred in smaller areas. The analysis supports the presence of savannas in Mexico and Central America, in the south of Southeast Asia, and in a few locations in western South America, where the model overestimates the occurrence of savannas. The estimated potential for lightning during the dry-wet season transition is relatively smaller in some parts of West Africa, where model and reference data are generally in good agreement. One major reason for these regional discrepancies may be the generalization of our analysis. For example, our large-scale definition of the transition between dry to wet seasons may not be an accurate estimate for all grid cells of the subregions. The use of climatological wind and precipitation data can hide inter-annual oscillations that may be important in some regions. Also, the coarse topographical data we used may not represent important regional features such as the narrow mountain ridges in Vietnam (Xie et al., 2006), which may affect our estimate of lightning potential in Southeast Asia. The generality of our analysis, however, was important for finding the simple parameterizations needed in environmental models at large temporal and spatial scales.

The determination of the physical boundaries between forests and savannas is a topic of active research. For example, Mills et al. (2006) suggest that the balance between grasses and trees may be entirely determined by climate. According to them, through evolutionary time, climate in fire-prone regions may favour either trees or herbaceous vegetation that resist or benefit from fires, which can be a proximate and supplementary factor. Mills et al. (2006) also propose that no single factor can be used to make distinctions between biomes, which should be recognized as complex and adaptive systems. Other studies, however, indicate that fires play a prominent role in determining the relative distribution of trees and grasses globally (e.g. Bond \& Keeley, 2005; Bond et al., 2005). The analyses from Bond and co-workers are based on new fire-exclusion experiments using dynamic global vegetation modelling, able to simulate plant growth with and without disturbance by fire. A major result from their simulations is the perspective for global extensive expansion of forests if fires were to be excluded from land ecosystems. This result is supported by observations in forest locations where fires were introduced by land use (Bond et al., 2005). 
Figure 5 Zonal wind and total lightning flashes climatologies at the transition from dry to wet season over land. In panel (a) the zonal wind at the $850 \mathrm{hPa}$ pressure level, and in (b) total (cloud-cloud and cloud-ground) lightning flashes per month (fls/mon). Panel (c) shows the areas where the zonal wind is $\geq 1.5$ $\mathrm{m} \mathrm{s}^{-1}$ (in grey). Wind climatological data are from the NCEP/NCAR reanalysis monthly means. Total lightning activity was detected by the LIS and OTD sensors from 1995 to 2003, and the data are from the Global Hydrology Resource Center.
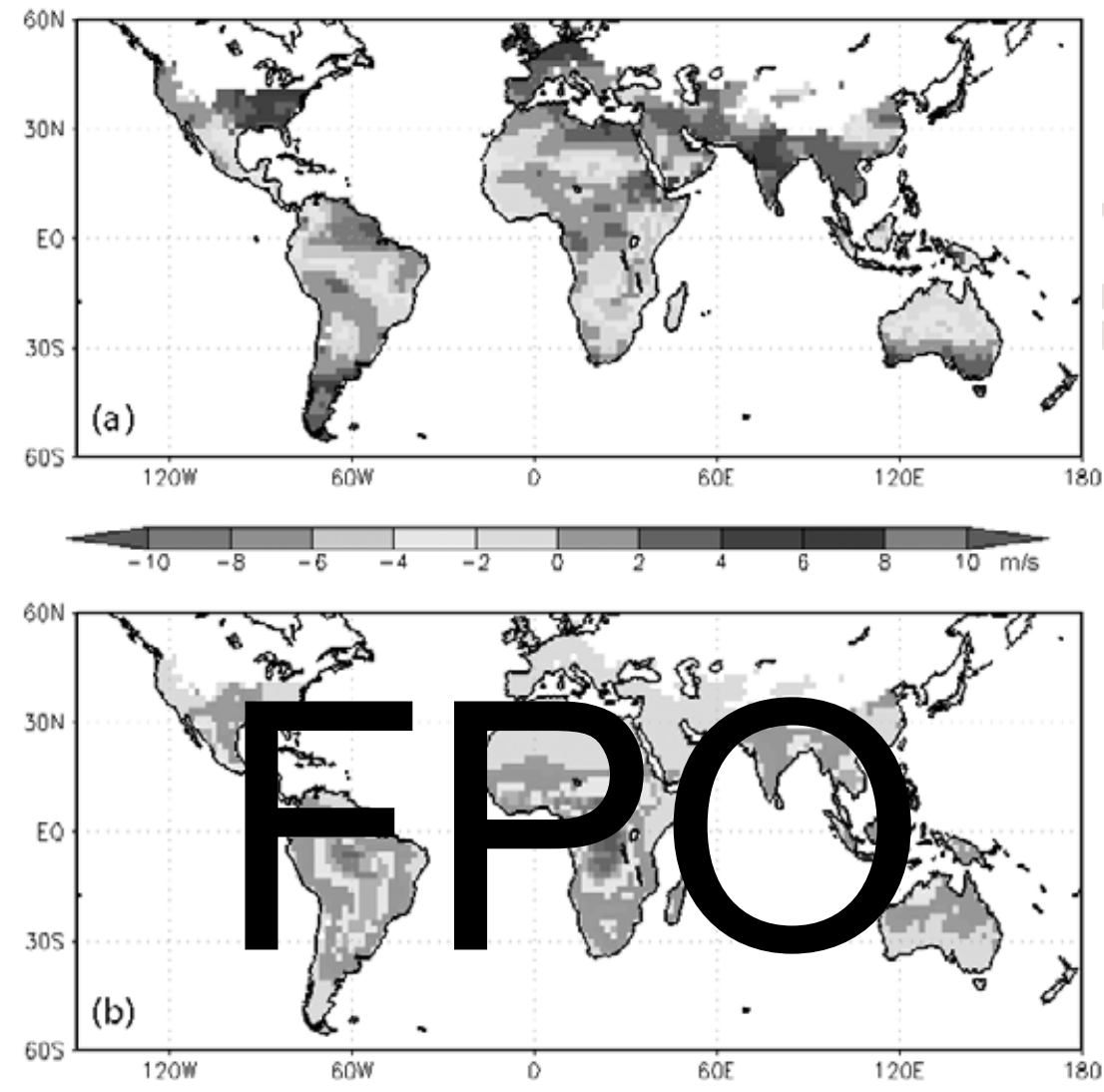

One implication of the lack of convergence in explaining what causes the globally observed tree/grass distribution is the related complexity required to build mechanistic large-scale models that capture and reproduce these patterns. For example, it is difficult to select and implement modelling factors that will explain all cases of tree-grass distribution and/or are able to account for evolutionary dynamics pointed by Mills et al. (2006). Our work is relatively similar to the work by Bond et al. (2005) in the sense that the position of savannas is mostly determined by climate, but it can be modified by the potential for fire. On the other hand, our simple rule was designed for fire-prone regions where we assume that fires are not limited by fuel/biomass or flammability but may be limited by ignition sources. Fire modules in Bond et al. (2005) assume that fires are mostly limited by flammability conditions, and ignition is random but always present.

A potential major outcome from this work is the contribution to building global models of fire occurrence that can account for the dynamics of natural sources of ignition. While perhaps too simplistic, our analyses and the new fire rule represent initial steps in the direction of physically based methods for considering lightning ignitions. It is important to stress that, though simple, 
M. F. Cardoso et al.

this parameterization allows for a dynamic coupling of the lighting source to the AGCM, which is a necessary condition for coupled biome-climate studies in all time scales, from the palaeoclimate to the climate of the future. As revised by Keane et al. (2004), complexity is a limiting factor for the development of ignition components of vegetation fire models based on a physical approach, which simulates ignition directly from environmental conditions such as lightning and fuel moisture. Our approach may be currently classified as somewhat between empirical and physical (Keane et al., 2004), because we use an empirical relationship between large-scale wind patterns and lightning potential that was inferred from a qualitative analysis based on lighting physics on a large scale.

To conclude, we mention important ways of making progress that we plan to attempt in the future. They mostly concentrate on moving towards physical approaches for estimating the dynamics of natural sources of ignition from lightning. At this point, our analyses are based on large-scale topography and climatological wind data. In future analysis, and as research explaining the correlations between satellite-based lightning detections and meteorological variables progresses, we may consider using remote-sensing lightning data directly to further evaluate our current results and to help select additional environmental factors for modelling fires. As suggested by Bowman (2005), lightning-activity data from satellites could be used to understand the relative importance of natural and human-induced sources of ignitions on the global patterns of vegetation and fires. Finally, major progress can be achieved by following the large-scale parameterization by Price \& Rind (1994), which is adopted for use with AGCMs and allows for differentiation between total and cloudto-ground lightning activity. This parameterization is based on the vertical structure of convective clouds, and can potentially be used to directly estimate the likelihood of fires caused by lightning.

\section{ACKNOWLEDGEMENTS}

We gratefully acknowledge the support of the Gordon and Betty Moore Foundation through the Environmental Conservation/ Andes-Amazon Initiative, the Brazilian Institute for Space Research (INPE) and the Large Scale Biosphere-Atmosphere Experiment in Amazonia (LBA) program. We also thank David Currie, Martin Sykes, David Bowman and two anonymous referees for constructive comments on drafts of this manuscript.

\section{REFERENCES}

Bachelet, D., Lenihan, J.M., Daly, C. \& Neilson, R.P. (2000) Interactions between fire, grazing and climate change at Wind Cave National Park, SD. Ecological Modelling, 134, 229244.

Barry, R.G. \& Chorley, R.J. (1998) Atmosphere, weather and climate, 7th edn. Routledge, New York.

Boccippio, D.J., Goodman, S.J. \& Heckman, S. (2000) Regional differences in tropical lightning distributions. Journal of Applied Meteorology, 39, 2231-2248.
Bonan, G. (2002) Ecological climatology: concepts and applications. Cambridge University Press, Cambridge.

Bond, W.J. \& Keeley, J.E. (2005) Fire as a global 'herbivore': the ecology and evolution of flammable ecosystems. Trends in Ecology \& Evolution, 20, 387-394.

Bond, W.J., Woodward, F.I. \& Midgley, G.F. (2005) The global distribution of ecosystems in a world without fire. New Phytologist, 165, 525-538.

Bowman, D. (2005) Understanding a flammable planet climate fire and global vegetation patterns. New Phytologist, 165, 341345.

Brown, T.J., Hall, B.L. \& Westerling, A.L. (2004) The impact of twenty-first century climate change on wildland fire danger in the western United States: an applications perspective. Climatic Change, 62, 365-388.

Cavalcanti, I.F.A., Marengo, J.A., Satyamurti, P., Nobre, C.A., Trosnikov, I., Bonatti, J.P., Manzi, A.O., Tarasova, T., Pezzi, L.P., D’Almeida, C., Sampaio, G., Castro, C.C., Sanches, M.B. \& Camargo, H. (2002) Global climatological features in a simulation using the CPTEC-COLA AGCM. Journal of Climate, 15, 2965-2988.

Cecil D.J., Goodman, S.J., Boccippio, D.J., Zipser, E.J. \& Nesbitt, S.W. (2005) Three years of TRMM precipitation features. Part I: radar, radiometric, and lightning characteristics. Monthly Weather Review, 133, 543-566.

Christian, H.J., Blakeslee, R.J., Boccippio, D.J., Boeck, W.L., Buechler, D.E., Driscoll, K.T., Goodman, S.J., Hall, J.M., Koshak, W.J., Mach, D.M. \& Stewart, M.F. (2003) Global frequency and distribution of lightning as observed from space by the Optical Transient Detector. Journal of Geophysical Research (Atmospheres), 108(D1), 4005, doi:10.1029/2002JD002347.

Cochrane, M.A. \& Schulze, M.D. (1999) Fire as a recurrent event in tropical forests of the eastern Amazon: effects on forest structure, biomass, and species composition. Biotropica, 31, 116.

Daly, C., Bachelet, D., Lenihan, J.M., Neilson, R.P., Parton, W. \& Ojima, D. (2000) Dynamic simulation of tree-grass interactions for global change studies. Ecological Applications, 10, $449-469$.

Dorman, J.L. \& Sellers, P.J. (1989) A global climatology of albedo, roughness length and stomatal resistance for atmospheric general circulation models as represented by the Simple Biosphere Model (SiB). Journal of Applied Meteorology, 28, 833-855.

Eyre, S.R. (1968) Vegetation and soils: a world picture. Edward Arnold, London.

Foley, J.A., Prentice, I.C., Ramankutty, N., Levis, S., Pollard, D., Sitch, S. \& Haxeltine, A. (1996) An integrated biosphere model of land surface processes, terrestrial carbon balance, and vegetation dynamics. Global Biogeochemical Cycles, 10, 603628.

Haxeltine, A. \& Prentice, I.C. (1996) BIOME3: an equilibrium terrestrial biosphere model based on ecophysiological constraints, resource availability, and competition among plant functional types. Global Biogeochemical Cycles, 10, 693709. 
Hickler, T., Prentice, I.C., Smith, B., Sykes, M.T. \& Zaehle, S. (2006) Implementing plant hydraulic architecture within the LPJ Dynamic Global Vegetation Model. Global Ecology and Biogeography, 15, 567-577.

Hoffmann, W.A., Bazzaz, F.A., Chatterton, N.J., Harrison, P.A. \& Jackson, R.B. (2000) Elevated $\mathrm{CO}_{2}$ enhances resprouting of a tropical savanna tree. Oecologia, 123, 312-317.

Holdridge, L.R. (1967) Life zone ecology. Tropical Science Center, San José, Costa Rica.

Jha, C.S. \& Singh, J.S. (1990) Composition and dynamics of dry tropical forest in relation to soil texture. Journal of Vegetation Science, 1, 609-614.

Kalnay, E., Kanamitsu, M., Kistler, R., Collins, W., Deaven, D., Gandin, L., Iredell, M., Saha, S., White, G., Woollen, J., Zhu, Y., Chelliah, M., Ebisuzaki, W., Higgins, W., Janowiak, J., Mo, K.C., Ropelewski, C., Wang, J., Leetmaa, A., Reynolds, R., Jenne, R. \& Joseph, D. (1996) The NCEP/NCAR 40-year reanalysis project. Bulletin of the American Meteorological Society, 77, 437-470.

Kauffman, J.B., Cummings, D.L. \& Ward, D.E. (1994) Relationships of fire, biomass and nutrient dynamics along a vegetation gradient in the Brazilian cerrado. Journal of Ecology, 74, 140151.

Keane, R.E., Cary, G., Davies, I.D., Flannigan, M.D., Gardner, R.H., Lavorel, S., Lennihan, J.M., Li, C. \& Rupp, T.S. (2004) A classification of landscape fire succession models: spatially explicit models of fire and vegetation dynamic. Ecological Modelling, 256, 3-27.

Keeley, J.E. \& Rundel, P.W. (2005) Fire and the Miocene expansion of $\mathrm{C}_{4}$ grasslands. Ecology Letters, 8, 683-690.

Kucharik, C.J. (2003) Evaluation of a process-based agro-ecosystem model (Agro-IBIS) across the U.S. cornbelt: simulations of the inter-annual variability in maize yield. Earth Interactions, 7, $1-33$.

Laurent, H., Machado, L.A.T., Morales, C.A. \& Durieux, L. (2002) Characteristics of the Amazonian mesoscale convective systems observed from satellite and radar during the WETAMC/LBA experiment. Journal of Geophysical Research, 107(D20), 8054

Matthews, E. (1983) Global vegetation and land use: New highresolution data bases for climate studies. Journal of Climate and Applied Meteorology, 22, 474-487.

McGregor, G.R. \& Nieuwolt, S. (1998) Tropical climatology: an introduction to the climates of the low latitudes, 2nd edn. John Wiley \& Sons, New York.

Mills, A.J., Rogers, K.H., Stalmans, M. \& Witkowski, E.T.F. (2006) A framework for exploring the determinants of savanna and grassland distribution. BioScience, 56, 579-589.

Mistry, J. (1998) Fire in the cerrado (savannas) of Brazil: an ecological review. Progress in Physical Geography, 22, 425-448.

Neilson, R.P. (1995) A model for predicting continental scale vegetation distribution and water balance. Ecological Applications, 5, 362-385.

Oyama, M.D. \& Nobre, C.A. (2003) A new climate-vegetation equilibrium state for Tropical South America. Geophysical Research Letters, 30, 2199-2203.
Oyama, M.D. \& Nobre, C.A. (2004a) Climatic consequences of a large-scale desertification in northeast Brazil: a GCM simulation study. Journal of Climate, 17, 3203-3213.

Oyama, M.D. \& Nobre, C.A. (2004b) A simple potential vegetation model for coupling with the Simple Biosphere Model (SiB). Revista Brasileira de Meteorologia, 19, 203-216.

Pearson, R.G. \& Dawson, T.P. (2003) Predicting the impacts of climate change on the distribution of species: are bioclimate envelope models useful? Global Ecology and Biogeography, 12, 361-371.

Pearson, R.G., Thuiller, W., Araújo, M.B., Martinez-Meyer, E., Brotons, L., McClean, C., Miles, L., Segurado, P., Dawson, T.E. \& Lees, D.C. (2006) Model-based uncertainty in species range prediction. Journal of Biogeography, 33, 1704-1711.

Petersen, W.A., Fu, R., Chen, M. \& Blakeslee, R. (2006) Intraseasonal forcing of convection and lightning activity in the southern Amazon as a function of cross-equatorial flow. Journal of Climate, 19, 3180-3196.

Petersen, W.A., Nesbitt, S.W., Blakeslee, R.J., Cifelli, R., Hein, P. \& Rutledge, S.A. (2002) TRMM observations of intraseasonal variability in convective regimes over the Amazon. Journal of Climate, 15, 1278-1294.

Pinto, I.R.C.A. \& Pinto, O., Jr (2003) Cloud-to-ground lightning distribution in Brazil. Journal of Atmospheric and Solar-Terrestrial Physics, 65, 733-737.

Prentice, I.C., Cramer, W., Harrison, S.P., Leemans, R., Monserud, R.A. \& Solomon, A. (1992) A global biome model based on plant physiology and dominance, soil properties and climate. Journal of Biogeography, 19, 117-134.

Price, C. \& Rind, D. (1994) Modeling global lightning distributions in a general circulation model. Monthly Weather Review, 122, 1930-1939.

Ramankutty, N. \& Foley, J.A. (1999) Estimating historical changes in global land cover: croplands from 1700 to 1992. Global Biogeochemical Cycles, 13, 997-1027.

Ramos-Neto M.B. \& Pivello, V.R. (2000) Lightning fires in a Brazilian savanna national park: Rethinking management strategies. Environment Management, 26, 675-684.

Rothermel, R.C. (1972) A mathematical model for predicting fire spread in wildland fuels. Research Paper INT-115, United States Department of Agriculture, Forest Service, Intermountain Forest and Range Experiment Station, Ogden, UT.

Sagar, R. \& Singh, J.S. (2005) Structure, diversity, and regeneration of tropical dry deciduous forest of northern India. Biodiversity and Conservation, 14, 935-959.

Schlesinger, W.H. (1997). Biogeochemistry: an analysis of global change, 2nd edn. Academic Press, San Diego, CA.

Scholes, R.J. \& Archer, S.R. (1997) Tree-grass interactions in savannas. Annual Review of Ecology and Systematics, 28, 517-544.

Schumaker, C. \& Houze, R.A. (2006) Stratiform precipitation production over sub-Saharan Africa and the tropical East Atlantic as observed by TRMM. Quarterly Journal of the Royal Meteorological Society, 132, 2235-2255.

Sklenar, P. \& Lægaard, S. (2003) Rain-shadow in the High Andes of Ecuador evidenced by páramo vegetation. Arctic, Antarctic, and Alpine Research, 35, 8-17. 


\section{F. Cardoso et al.}

Takayabu, Y.N. (2006) Rain-yield per flash calculated from TRMM PR and LIS data and its relationship to the contribution of tall convective rain. Geophysical Research Letters, 33, L18705.

Uhl, C. \& Kauffman, J.B. (1990). Deforestation, fire susceptibility, and potential tree responses to fire in the eastern Amazon. Ecology, 71, 437-449.

Whittaker, R.H. (1975) Communities and ecosystems, 2nd edn. Macmillan, New York.

Willmott, C.J. \& Matsuura, K. (1998) Global air temperature and precipitation: regridded monthly and annual climatologies, Willmott, Matsuura and Legates database v2.01. Center for Climatic Research, Department of Geography, University of Delaware, Newark, DE.

Xie, S.-P., Xu, H., Saji, N.H., Wang, Y. \& Liu, W.T. (2006) Role of narrow mountains in large-scale organization of Asian monsoon convection. Journal of Climate, 19, 3420-3429.

\section{BIOSKETCHES}

Manoel Cardoso is a post-doctoral research associate at the Brazilian Center for Weather Forecasting and Climate Studies (CPTEC-INPE). His broad research interests include the dynamics and consequences of vegetation fires in tropical regions, biosphere-atmosphere interactions and environmental modelling.

Carlos A. Nobre is a senior scientist at the Brazilian Center for Weather Forecasting and Climate Studies (CPTEC-INPE) and Chair of the Scientific Committee of the International Geosphere-Biosphere Programme (IGBP). His research interests include biosphereatmosphere interactions, climate modelling, tropical meteorology and global change.

Editor: Martin Sykes 


\section{Author Query Form}

\section{Journal: Global Ecology \& Biogeography}

\section{Article: geb_356.fm}

Dear Author,

During the copy-editing of your paper, the following queries arose. Please respond to these by marking up your proofs with the necessary changes/additions. Please write your answers on the query sheet if there is insufficient space on the page proofs. Please write clearly and follow the conventions shown on the attached corrections sheet. If returning the proof by fax do not write too close to the paper's edge. Please remember that illegible mark-ups may delay publication.

Many thanks for your assistance.

\begin{tabular}{|l|l|l|}
\hline No. & Query & Remarks \\
\hline $\mathbf{1}$ & $\begin{array}{l}\text { 'large temporal and spatial scale biosphere-atmosphere interactions for } \\
\text { climate and environmental studies' changed to 'biosphere-atmosphere } \\
\text { interactions on a large temporal and spatial scale for climate and } \\
\text { environmental studies'. }\end{array}$ & \\
\hline $\mathbf{2}$ & 'in correspondence to' changed to 'corresponding to' & \\
\hline $\mathbf{3}$ & 'appropriated' changed to 'used' & \\
\hline $\mathbf{4}$ & $\begin{array}{l}\text { Figures 1-5 is in poor quality, please resupply. For more information about } \\
\text { supplying electronic artwork, please see the journal webpage or Blackwell's } \\
\text { illectronic artwork guidelines at http://www.blackwellpublishing.com/bauthor/ }\end{array}$ & \\
\hline $\mathbf{5}$ & there is no category (12). Is this OK? & \\
\hline $\mathbf{6}$ & 'most of the burned area occurred' changed to 'most of the burning occurred' & \\
\hline
\end{tabular}




\section{Please correct and return this set}

Please use the proof correction marks shown below for all alterations and corrections. If you wish to return your proof by fax you should ensure that all amendments are written clearly in dark ink and are made well within the page margins.

\begin{tabular}{|c|c|c|}
\hline Instruction to printer & Textual mark & Marginal mark \\
\hline Leave unchanged & ... under matter to remain & (1) \\
\hline $\begin{array}{l}\text { Insert in text the matter } \\
\text { indicated in the margin }\end{array}$ & $\Lambda$ & $\begin{array}{l}\text { New matter followed by } \\
h \text { or } h \otimes\end{array}$ \\
\hline Delete & $\begin{array}{l}\text { / through single character, rule or underline } \\
\text { or } \\
\qquad \text { through all characters to be deleted }\end{array}$ & $\sigma$ or $\sigma_{\otimes}$ \\
\hline $\begin{array}{l}\text { Substitute character or } \\
\text { substitute part of one or } \\
\text { more word(s) }\end{array}$ & 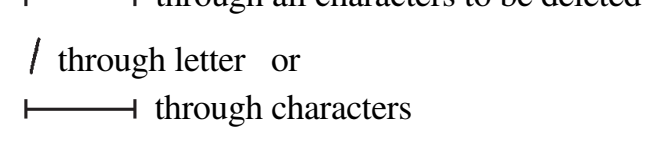 & $\begin{array}{l}\text { new character / or } \\
\text { new characters / }\end{array}$ \\
\hline Change to italics & — under matter to be changed & $\leftarrow$ \\
\hline Change to capitals & $\equiv$ under matter to be changed & $\equiv$ \\
\hline Change to small capitals & $=$ under matter to be changed & $=$ \\
\hline Change to bold type & $\sim$ under matter to be changed & $\sim$ \\
\hline Change to bold italic & $\bar{\sim}$ under matter to be changed & $\widehat{s}$ \\
\hline Change to lower case & Encircle matter to be changed & $\neq$ \\
\hline Change italic to upright type & (As above) & 4 \\
\hline Change bold to non-bold type & (As above) & np \\
\hline Insert 'superior' character & $\begin{array}{l}\text { / through character or } \\
K \text { where required }\end{array}$ & $\begin{array}{l}y \text { or } y \\
\text { under character } \\
\text { e.g. } y \text { or } \dot{x}\end{array}$ \\
\hline Insert 'inferior' character & (As above) & $\begin{array}{l}\alpha \\
\text { over character } \\
\text { e.g. } \hat{\imath}\end{array}$ \\
\hline Insert full stop & (As above) & $\odot$ \\
\hline Insert comma & (As above) & , \\
\hline Insert single quotation marks & (As above) & $\begin{array}{l}\dot{y} \text { or } \dot{x} \text { and/or } \\
\dot{y} \text { or } \dot{x}\end{array}$ \\
\hline Insert double quotation marks & (As above) & $\begin{array}{l}\ddot{y} \text { or } \ddot{x} \text { and/or } \\
\ddot{y} \text { or } \ddot{x}\end{array}$ \\
\hline Insert hyphen & (As above) & $H$ \\
\hline Start new paragraph & - & 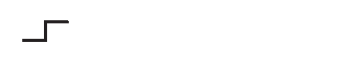 \\
\hline No new paragraph & 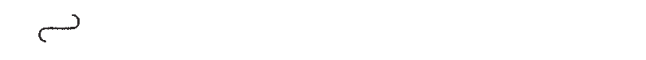 & 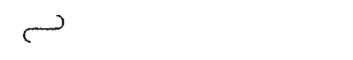 \\
\hline Transpose & $\sqcup$ & $\sqcup$ \\
\hline Close up & linking $\bigcirc$ characters & \\
\hline $\begin{array}{l}\text { Insert or substitute space } \\
\text { between characters or words }\end{array}$ & $\begin{array}{l}\text { I through character or } \\
\alpha \text { where required }\end{array}$ & $Y$ \\
\hline $\begin{array}{l}\text { Reduce space between } \\
\text { characters or words }\end{array}$ & $\begin{array}{l}\text { between characters or } \\
\text { words affected }\end{array}$ & $\uparrow$ \\
\hline
\end{tabular}

